\title{
Metabolic Relationships among the Plasma Lipoproteins
}

\author{
RECIPROCAL CHANGES IN THE CONCENTRATIONS OF \\ VERY LOW AND LOW DENSITY LIPOPROTEINS
}

IN MAN

\author{
Dana E. Wilson and Robert S. LeES \\ From the Clinical Research Center and the Department of Nutrition and Food \\ Science, Massachusetts Institute of Technology, \\ Cambridge, Massachusetts 02142
}

A B S T R A C T The changes in other plasma lipoproteins which accompany alterations in very low density lipoproteins (VLDL) were studied in 31 normal and hyperlipidemic men and women who underwent weight reduction, carbohydrate induction, or clofibrate treatment. Plasma lipids and individual lipoprotein cholesterol concentrations were measured serially during control and treatment periods. Low density lipoprotein (LDL) protein was determined by radial immunodiffusion. Oppositely directed changes in VLDL and LDL were found with each of the three metabolic perturbations. Changes in high density lipoprotein (HDL) cholesterol generally paralleled those in LDL but were less consistent. Two patients with type III hyperlipoproteinemia failed to demonstrate reciprocal increases in LDL despite more than $40 \%$ reduction in plasma glycerides or VLDL with weight reduction or clofibrate therapy. After clofibrate therapy, LDL increased in proportion to the absolute decrease in VLDL cholesterol during treatment. LDL protein changed relatively less than did LDL cholesterol. The mechanism for the interdependency of plasma VLDL and LDL concentrations over the long term is not known and may be the result of altered rates of interconversion of these lipoproteins, or to feedback inhibition by VLDL of LDL production and release.

\section{INTRODUCTION}

The regular occurrence of simultaneous or sequential changes in concentrations of different plasma lipopro-

Dr. Wilson's present address is the Department of Internal Medicine, University of Utah Medical Center, Salt Lake City, Utah.

Received for publication 10 May 1971 and in revised form 1 November 1971. tein classes may reflect biochemical relationships between individual lipoprotein species and thus provide insight into their metabolic regulation. Such relationships are of particular interest for very low density $(\mathrm{VLDL})^{1}$ and low density lipoproteins (LDL), since the existence of a precursor-product relationship between the two has been suggested. Shared apoprotein antigens $(1,2)$ and the appearance of radioiodinated, injected VLDL protein in $\operatorname{LDL}(3,4)$, have led to the hypothesis that some, if not all, of the plasma LDL arises from VLDL catabolism $(3,4)$.

Parallel changes in VLDL and LDL occur with advancing age (5) or nicotinic acid therapy (6). By contrast, patients have shown reciprocal changes in VLDL and LDL or high density lipoprotein (HDL) in a variety of circumstances. To examine these relationships systematically, we have studied lipoprotein concentration and composition in man during changes in VLDL concentration induced by weight loss, carbohydrate induction, and clofibrate treatment.

\section{METHODS}

Subjects were referred to the M.I.T. Clinical Research Center for diagnosis and treatment of hyperlipidemia. Two normal young women (patients 12 and 31) were included in the carbohydrate induction experiments. Table I summarizes the salient clinical and laboratory data.

Inpatient studies were performed on the ward of the Clinical Research Center and were generally of 6 months duration. Inpatients were fed liquid formula diets supplemented with minerals and vitamins (7). Basal formula diets consisted of $10 \%$ of calories as milk or soy protein, $50 \%$ of calories as carbohydrate (Dextri-maltose or Cerelose), and $40 \%$ fat calories. The latter were added as lard

${ }^{1}$ Abbreviations used in this paper: $\mathrm{C} / \mathrm{P}$, cholesterol-protein ratio; HDL, high density lipoprotein; LDL, low density lipoprotein; $\mathrm{P} / \mathrm{S}$, polyunsaturated/saturated fat ratio. 
TABLE I

Initial Clinical, and Laboratory Data in the 27 Study Patients

\begin{tabular}{|c|c|c|c|c|c|c|c|c|c|c|}
\hline $\begin{array}{c}\text { Patient } \\
\text { No. }\end{array}$ & Age & Sex & Diagnosis & $\begin{array}{c}\text { Lipo- } \\
\text { protein } \\
\text { phenotype } \\
\text { (22) }\end{array}$ & Glycerides & $\begin{array}{c}\text { Total } \\
\text { choles- } \\
\text { terol }\end{array}$ & $\begin{array}{l}\text { VLDL } \\
\text { choles- } \\
\text { terol }\end{array}$ & $\begin{array}{l}\text { LDL } \\
\text { choles- } \\
\text { terol }\end{array}$ & $\begin{array}{l}\text { LDL } \\
\text { protein }\end{array}$ & $\begin{array}{l}\text { HDL } \\
\text { choles- } \\
\text { terol }\end{array}$ \\
\hline & & & & & & & $\mathrm{mg} / 10$ & & & \\
\hline \multicolumn{11}{|c|}{ Weight reduction } \\
\hline 1 & 54 & $\mathbf{M}$ & Obesity & IV & 1109 & 302 & 186 & 97 & 75 & 19 \\
\hline 2 & 37 & $\mathbf{M}$ & Obesity & IV & 923 & 231 & 186 & 75 & 75 & 20 \\
\hline 3 & 48 & $\mathbf{M}$ & Obesity, xanthelasma & III & 636 & 299 & 210 & 77 & 40 & 12 \\
\hline 4 & 61 & $\mathbf{M}$ & Obesity, CAD, MI & IV & 392 & 157 & 72 & 72 & 68 & 13 \\
\hline 5 & 53 & $\mathbf{M}$ & Obesity, gout & IV & 357 & 186 & 85 & 72 & 64 & 29 \\
\hline 6 & 49 & $\mathbf{M}$ & Obesity, hypertension & IV & 258 & 224 & 82 & 108 & 90 & 34 \\
\hline \multicolumn{11}{|c|}{ Carbohydrate induction } \\
\hline $7 *$ & 60 & $\mathbf{M}$ & $\mathrm{CAD}$, angina, obesity & IV & 625 & 267 & 122 & 123 & 114 & 22 \\
\hline $8 *$ & 49 & $\mathbf{M}$ & $\mathrm{CAD}$, angina pectoris & II & 423 & 524 & 107 & 379 & 212 & 38 \\
\hline 9* & 50 & $\mathbf{F}$ & CAD, angina, obesity & IV & 310 & 229 & 91 & 110 & 98 & 28 \\
\hline $10 *$ & 35 & $\mathbf{M}$ & CAD, MI, sudden death & II & 204 & 275 & 24 & 223 & 137 & 28 \\
\hline $11 *$ & 35 & $\mathbf{M}$ & CAD, MI, sudden death & II & 177 & 265 & 13 & 214 & 106 & 38 \\
\hline $12 *$ & 19 & $\mathbf{F}$ & Normal & Normal & 44 & 110 & 9 & 80 & 30 & 21 \\
\hline $13 *$ & 19 & $\mathbf{F}$ & Normal & Normal & 23 & 115 & 26 & 104 & 73 & 25 \\
\hline \multicolumn{11}{|c|}{ Clofibrate treatment } \\
\hline 14 & 30 & $\mathbf{M}$ & Asymptomatic & $\mathbf{V}$ & 2922 & 329 & 280 & 37 & 43 & 13 \\
\hline $15^{*}$ & 56 & $\mathbf{F}$ & Obesity, CAD, angina & IV & 2662 & 432 & 375 & 37 & 41 & 22 \\
\hline $16^{*}$ & 35 & $\mathbf{M}$ & Abdominal pain, eruptive xanthoma & V & 2241 & 325 & 277 & 33 & 38 & 15 \\
\hline 17 & 31 & $\mathbf{M}$ & Asymptomatic & $\mathbf{V}$ & 1372 & 525 & 477 & 35 & 41 & 13 \\
\hline $18 *$ & 48 & $\mathbf{M}$ & CAD, angina, cerebral ischemia & III & 394 & 425 & 200 & 185 & 72 & 40 \\
\hline 19 & 44 & $\mathbf{M}$ & CAD, sudden death & IV & 380 & 232 & 70 & 138 & 100 & 24 \\
\hline $\begin{array}{l}20^{*} \\
21\end{array}$ & $\begin{array}{l}52 \\
50\end{array}$ & $\begin{array}{l}\mathbf{M} \\
\mathbf{M}\end{array}$ & $\begin{array}{l}\text { Possible CAD } \\
\text { Asymptomatic }\end{array}$ & III & $\begin{array}{l}291 \\
286\end{array}$ & $\begin{array}{l}309 \\
293\end{array}$ & $\begin{array}{r}154 \\
54\end{array}$ & $\begin{array}{l}123 \\
207\end{array}$ & $\begin{array}{r}62 \\
116\end{array}$ & $\begin{array}{l}32 \\
32\end{array}$ \\
\hline 22 & 50 & $\mathbf{M}$ & Asymptomatic & II & 278 & 295 & 48 & 218 & 132 & 29 \\
\hline 23 & 44 & $\mathbf{M}$ & Asymptomatic & IIf & 277 & 277 & 44 & 207 & 135 & 26 \\
\hline 24 & 49 & $\mathbf{M}$ & Peripheral vascular disease & II & 160 & 384 & 22 & 316 & 147 & 46 \\
\hline 25 & 36 & $\mathrm{~F}$ & $\mathrm{CAD}$ & II & 144 & 234 & 15 & 193 & 112 & 26 \\
\hline 26 & 18 & $\mathbf{F}$ & Asymptomatic & II & 50 & 333 & 13 & 287 & 130 & 33 \\
\hline 27 & 39 & $\mathbf{F}$ & Xanthomatosis & II & 47 & 426 & 12 & 370 & 177 & 44 \\
\hline
\end{tabular}

Coronary artery disease (CAD), either myocardial infarction (MI), or angina pectoris was present in 11 of the 27 patients.

* Inpatient studies.

† Type II with hyperprebetalipoproteinemia on a free diet.

(lard formula). The approximate cholesterol content of the lard formula was $75 \mathrm{mg} / 1000 \mathrm{cal}$. Carbohydrate induction was produced by feeding a formula with $10 \%$ protein and 90\% carbohydrate (Dextri-maltose) calories (fat-free formula). Patients were weighed daily on a metabolic scale and caloric intake was adjusted to maintain constant body weight.

Outpatients were given a thorough medical examination and interviewed by a dietitian. Laboratory investigations were repeated at $2-$ to 8 -wk intervals. Outpatients were instructed in diet selection and preparation and met with the dietitian regularly. The diets included a basic diet $(40 \%$ mixed fat with a polyunsaturated/saturated fat $[\mathrm{P} / \mathrm{S}]$ ratio of about 1.5, 25-40\% carbohydrate, and 15-20\% protein), weight-reducing diets with a similar caloric distribution, and a low cholesterol (200-300 mg/day), high P/S (2.03.0) diet for the type II patients. Appropriate dietary therapy always preceded drug therapy which was started or changed only when stable lipid and lipoprotein values had been obtained on three consecutive occasions. Clofibrate was given by mouth at a dose of $1 \mathrm{~g}$ twice daily.

Patients were bled after a $12-16 \mathrm{hr}$ overnight fast; blood was collected in tubes containing disodium ethylenediaminetetraacetate (EDTA), $1 \mathrm{mg} / \mathrm{ml}$ of blood. Plasma was separated by low speed centrifugation at $4^{\circ} \mathrm{C}$. Lipoprotein electrophoresis of whole plasma and of the supernates and infranates after ultracentrifugation at density $1.006 \mathrm{~g} / \mathrm{ml}$ was performed on each sample to establish the lipoprotein phenotype and to confirm the ultracentrifugal separation of VLDL from HDL and LDL before lipoprotein quantitation. The diagnosis of type II hyperlipoproteinemia was made on the basis of a consistent elevation of LDL-cholesterol concentration in untreated patients. Patients with hyperprebetalipoproteinemia and hyperbetalipoproteinemia ("type II B") are specified in Table I.

Cholesterol and glycerides were measured by an AutoAnalyzer $(8-10)$. The interassay coefficients of variation for replicate samples were $3.4 \%, \mathrm{n}=29$ and $8.2 \%, \mathrm{n}=30$ for cholesterol and glycerides, respectively. HDL cholesterol was measured directly in the supernate of plasma after precipitation of LDL and VLDL with dextran sulfate and calcium chloride (10). The sum of LDL and HDL-cholesterol concentrations was measured in the density 1.006 infranatant fraction after ultracentrifugation of plasma. LDL and VLDL cholesterol were then calculated by difference (10):

$$
\begin{aligned}
\text { [LDL cholesterol }]= & {[\text { Density } 1.006 \text { inf ranate cholesterol }] } \\
& -[\text { HDL cholesterol }], \\
& \text { and } \\
\text { [VLDL cholesterol }]= & {[\text { Total plasma cholesterol }]-\text { density } } \\
& 1.006 \text { infranate cholesterol }] .
\end{aligned}
$$


A comparison of direct VLDL cholesterol measurement in density 1.006 supernates and the indirect method showed close agreement $(r=0.943, \mathrm{n}=72)$.

LDL-protein concentration was determined by radial immunodiffusion of plasma in agarose gel containing antiserum against human LDL prepared in rabbits. The concentration of LDL protein in unknown samples was obtained by comparison of the areas of the precipitin rings with those of a series of LDL standards for which the protein concentrations were known (11). The cholesterol-protein ratio $(\mathrm{C} / \mathrm{P})$ was calculated as an index of LDL composition as reported elsewhere (11). The interassay coefficient of variation for LDL protein was about $10 \%$. Data were stored in an IBM $360-75$ computer. Statistical and display programs were provided by S. S. David and R. Warren of M.I.T.'s Charles Stark Draper Laboratory.

Mean values for control and treatment periods of individual patients were compared by Student's $t$ test and by the Wilcoxon sign-rank test for paired data. The results were similar and $t$ test results were used, except in the case of HDL cholesterol, for which both statistics are given. For HDL-cholesterol values, the sign-rank test results are believed to be more accurate, since the data are grossly nonparametric in nature. Per cent change was calculated from the expression: (initial value) - (final value) $\div$ (initial value) $\times 100$.

Subjects were excluded from the study if alcohol intake appeared to be a factor in the genesis of their hyperlipidemia. Weight reduction patients were included only when there was a $40 \%$ or greater fall in plasma glyceride concentration.

\section{RESULTS}

Weight reduction. Six outpatients successfully lost weight and decreased their plasma glyceride concentration by $40 \%$ or more with therapeutic caloric re-

TABLE II

Lipoprotein and Lipid Values in the Patients who Demonstrated a Change of $40 \%$ or More in Plasma Glycerides from Control $(C)$ to Treatment $(T)$ Periods

\begin{tabular}{|c|c|c|c|c|c|c|c|c|c|c|c|c|c|c|}
\hline \multirow{2}{*}{$\begin{array}{c}\text { Patient } \\
\text { No. }\end{array}$} & \multicolumn{2}{|c|}{ Glyceride } & \multicolumn{2}{|c|}{$\begin{array}{c}\text { VLDL } \\
\text { cholesterol }\end{array}$} & \multicolumn{2}{|c|}{$\begin{array}{c}\text { LDL } \\
\text { cholesterol }\end{array}$} & \multicolumn{2}{|c|}{$\begin{array}{l}\text { LDL } \\
\text { protein }\end{array}$} & \multicolumn{2}{|c|}{$\begin{array}{c}\text { LDL-C/P } \\
\text { ratio }\end{array}$} & \multicolumn{2}{|c|}{$\begin{array}{c}\text { HDL } \\
\text { cholesterol }\end{array}$} & \multicolumn{2}{|c|}{$\begin{array}{l}\text { Number of } \\
\text { observations }\end{array}$} \\
\hline & C & $\mathrm{T}$ & c & $\mathrm{T}$ & C & $\mathrm{T}$ & C & $\mathbf{T}$ & c & $\mathbf{T}$ & C & $T$ & $\mathrm{C}$ & $\mathbf{T}$ \\
\hline & \multicolumn{2}{|c|}{$m g / 100 m l$} & \multicolumn{2}{|c|}{$m g / 100 m l$} & \multicolumn{2}{|c|}{$m g / 100 m l$} & \multicolumn{2}{|c|}{$m g / 100 m l$} & & & \multicolumn{2}{|c|}{$m g / 100 m l$} & & \\
\hline \multicolumn{15}{|c|}{ Weight reduction, $(n=6)$} \\
\hline 1 & 1109 & 243 & 186 & 60 & 97 & 166 & 75 & 116 & 1.23 & 1.42 & 19 & 33 & 1 & 1 \\
\hline 2 & 923 & 173 & 186 & 73 & 75 & 150 & 75 & 94 & 0.99 & 1.58 & 20 & 46 & 1 & 1 \\
\hline $3^{*}$ & $636^{*}$ & $201^{*}$ & $210^{*}$ & $81^{*}$ & $77^{*}$ & $82 *$ & $40^{*}$ & $41^{*}$ & $1.89^{*}$ & $1.99 *$ & $12^{*}$ & $24^{*}$ & 1 & 1 \\
\hline 4 & 392 & 142 & 72 & 28 & 72 & 125 & 68 & 72 & 1.05 & 1.72 & 13 & 25 & 1 & 1 \\
\hline 5 & 308 & 102 & 75 & 31 & 77 & 138 & 61 & 75 & 1.24 & 1.83 & 29 & 31 & 1 & 1 \\
\hline \multirow[t]{2}{*}{6} & 258 & 81 & 82 & 16 & 108 & 149 & 90 & 93 & 1.19 & 1.59 & 34 & 35 & 1 & 1 \\
\hline & \multicolumn{2}{|c|}{$P<0.05$} & \multicolumn{2}{|c|}{$P<0.02$} & \multicolumn{2}{|c|}{$P<0.001$} & \multicolumn{2}{|c|}{$P<0.05$} & \multicolumn{2}{|c|}{$P<0.01$} & \multicolumn{2}{|c|}{$P<0.05^{*}$} & & \\
\hline \multicolumn{15}{|c|}{ Carbohydrate induction, $(\mathrm{n}=7)$} \\
\hline 7 & 635 & 2266 & 125 & 289 & 140 & 71 & 117 & 86 & 1.20 & 0.82 & 23 & 15 & 7 & 3 \\
\hline 8 & 589 & 820 & 119 & 155 & 240 & 143 & 157 & 119 & 1.54 & 1.19 & 19 & 19 & 6 & 7 \\
\hline 9 & 395 & 644 & 81 & 102 & 106 & 65 & 80 & 58 & 1.36 & 1.15 & 20 & 16 & 10 & 4 \\
\hline 10 & 207 & 519 & 36 & 86 & 147 & 74 & 87 & 68 & 1.59 & 1.07 & 18 & 12 & 9 & 7 \\
\hline 11 & 131 & 366 & 21 & 67 & 127 & 110 & 72 & 80 & 1.78 & 1.34 & 29 & 12 & 11 & 4 \\
\hline 12 & 36 & 110 & 9 & 20 & 77 & 57 & 38 & 43 & 2.05 & 1.36 & 25 & 21 & 4 & 4 \\
\hline \multirow[t]{2}{*}{13} & 97 & 140 & 22 & 24 & 104 & 82 & 61 & 67 & 1.53 & 1.22 & 30 & 24 & 4 & 4 \\
\hline & \multicolumn{2}{|c|}{ NS } & \multicolumn{2}{|c|}{$0.05<P<0.1$} & \multicolumn{2}{|c|}{$P<0.01$} & \multicolumn{2}{|c|}{ NS } & $P<$ & .001 & $P<$ & .02 & & \\
\hline Clofibrat & treatme & , $(\mathrm{n}=$ & & & & & & & & & & & & \\
\hline 14 & 2916 & 1048 & 288 & 184 & 33 & 93 & 44 & 93 & 0.75 & 0.98 & 12 & 13 & 4 & 3 \\
\hline 15 & 982 & 258 & 156 & 37 & 78 & 182 & 53 & 88 & 1.47 & 1.83 & 19 & 25 & 10 & 14 \\
\hline 16 & 1253 & 346 & 171 & 53 & 34 & 124 & 33 & 78 & 1.01 & 1.59 & 12 & 19 & 8 & 13 \\
\hline 17 & 2159 & 303 & 500 & 88 & 39 & 149 & 48 & 93 & 0.81 & 1.49 & 12 & 25 & 2 & 5 \\
\hline $18^{*}$ & $524^{*}$ & $272^{*}$ & $173^{*}$ & $91^{*}$ & $121^{*}$ & $136^{*}$ & $48^{*}$ & $52^{*}$ & $2.49^{*}$ & $2.67^{*}$ & $17^{*}$ & $18^{*}$ & 12 & 9 \\
\hline 19 & 644 & 269 & 103 & 50 & 136 & 222 & 102 & 144 & 1.32 & 1.54 & 26 & 28 & 3 & 2 \\
\hline $20^{*}$ & $514^{*}$ & $169^{*}$ & $191^{*}$ & $44^{*}$ & $152^{*}$ & $135^{*}$ & $60^{*}$ & $58^{*}$ & $2.54^{*}$ & $2.31^{*}$ & $21^{*}$ & $33^{*}$ & 4 & 10 \\
\hline 25 & 170 & 136 & 45 & 12 & 149 & 189 & 90 & 105 & 1.68 & 1.79 & 32 & 29 & 7 & 6 \\
\hline & $P<$ & & $P<$ & .05 & $P<$ & 001 & $P<$ & .001 & $P<$ & .02 & $P=$ & $.05 \ddagger$ & & \\
\hline
\end{tabular}

* Data from type III patients were not included in determining the significance $(P)$ of the difference between $\mathrm{C}$ and $\mathrm{T}$ periods by Student's $t$ test for paired data.

$\ddagger$ Not significantly different by Student's $t$ test; significantly different with the indicated probability by the Wilcoxon sign-rank test for nonparametric data. 

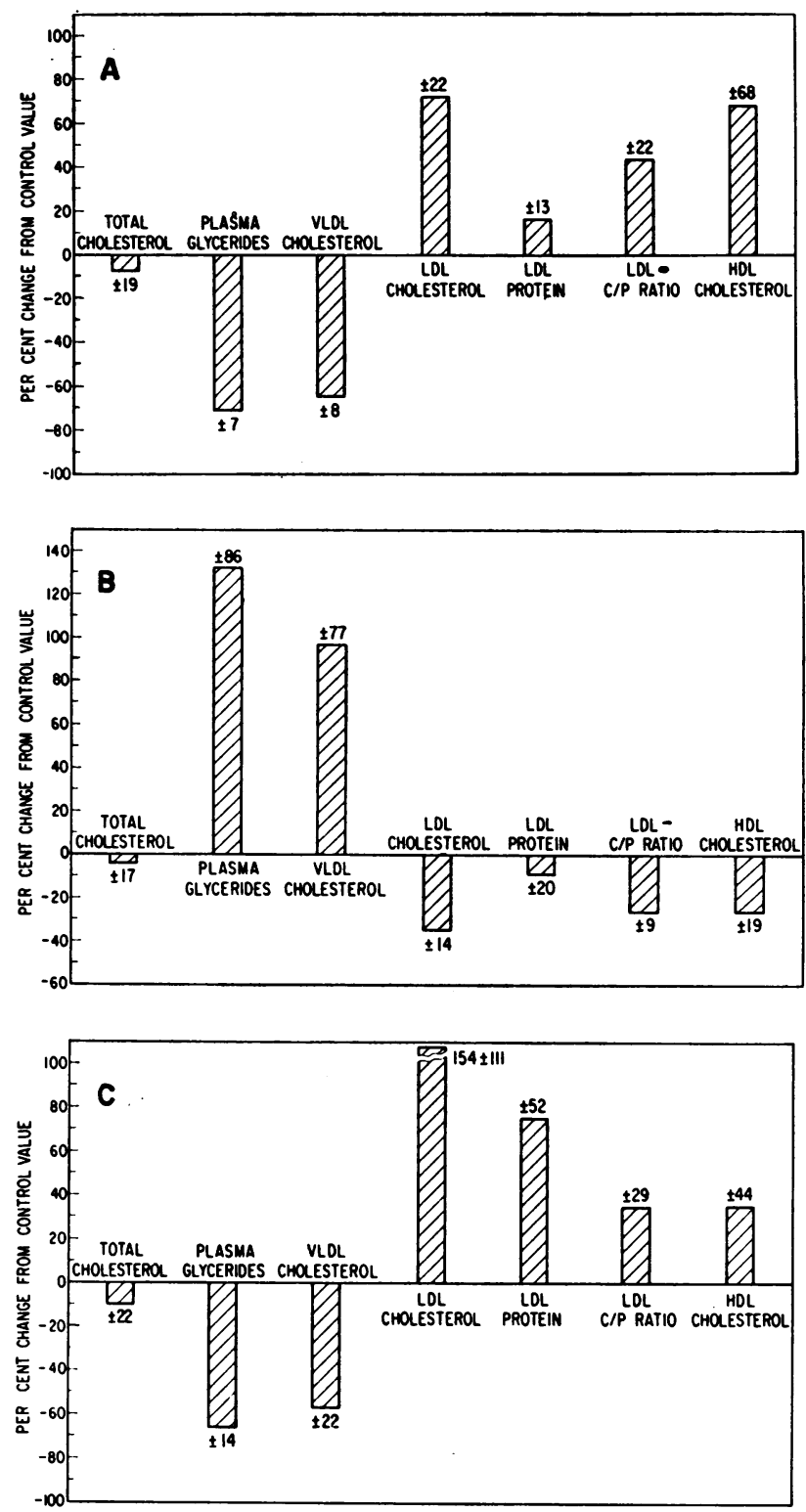

FIgure 1 Per cent change \pm sD from control periods in plasma lipids, lipoprotein cholesterol, and protein concentrations for: $A$, weight reduction; $B$, carbohydrate induction; and $C$, clofibrate treatment.

striction (mean change from initial body weight was $-12.0 \%$, range -7.5 to $-18.1 \%$ ). Single values at maximum and minimum weights were compared.

Lipid and lipoprotein changes for these six patients are shown in Table II and Fig. 1. In the type IV patients, LDL cholesterol and $\mathrm{C} / \mathrm{P}$ ratio rose by 72.4 and $43.1 \%$, respectively. The rise in LDL protein was slight $(18.2 \pm 13 \%, P<0.05)$. There was a $68 \%$ mean rise in HDL-cholesterol concentration although individual response was highly variable $(P<0.05)$.
Patient 3 with type III hyperlipoproteinemia was unique, since his LDL cholesterol and LDL protein failed to change with weight reduction, even though the decrease in plasma glycerides, weight, and VLDL cholesterol were comparable with those of the type IV patients. LDL-C/P in patient 3 was high initially and rose only slightly during weight reduction.

Carbohydrate induction. The values for mean plasma lipid and lipoprotein concentrations during control and carbohydrate induction periods are shown in Table II and Fig. 1. Mean body weight did not change from control to induction periods (range $98.8-101.8 \%$ of control). Plasma glycerides and VLDL cholesterol rose 134 and $96.4 \%$, respectively. Total cholesterol fell slightly. In each subject, cholesterol and LDL-C/P ratio fell $(P<0.01$ and $<0.001$, respectively). There was no consistent change in LDL-protein concentration (mean $-9.0 \%$ from control mean, $P>0.1$ ). HDL cholesterol fell $26 \%(P<0.02)$.

Clofibrate treatment. 14 patients had undergone control and clofibrate treatment periods of sufficient duration to permit analysis (10-80 wk, Table II). Control and treatment weights did not differ (mean treatment weights were 98.4 to $101.7 \%$ of control). 8 of the 14 experienced decreases in mean glyceride concentration of at least $40 \%$ from control values (Table II). A representative study is shown in Fig. 2 (patient 15). The responses of the two type III patients, 18 and 20 , differed from the rest of the group despite comparable changes in plasma glycerides and VLDL cholesterol. In the type III patients, LDL cholesterol, LDL protein, and LDL-C/P ratio did not change appreciably. The remaining six of the eight responders had increases in mean LDL cholesterol $(154 \%, P<0.001)$, mean LDL protein $(74.2 \%, P<0.001)$, and mean LDL-C/P ratio $(39.4 \%, P<0.02)$ (Fig. 1$)$. The per cent changes in LDL cholesterol, LDL protein, and

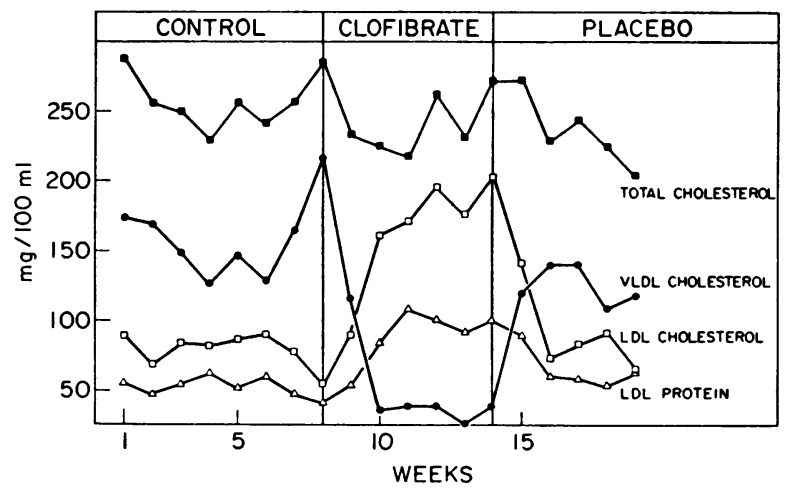

FIGURE 2 Lipoprotein cholesterol and protein concentrations during control, clofibrate, and placebo periods in patient 15. 
LDL-C/P ratio correlated with the absolute change in VLDL cholesterol concentration during clofibrate treatment for all except the two type III patients (Fig. $3)$. The absolute changes in LDL cholesterol, LDL protein, and LDL-C/P also correlated significantly with the absolute change in VLDL cholesterol but to a lesser degree $(r=-0.648,-0.572$, and -0.785 , respectively, all significant at $P=0.05$ ). Thus the proportional changes in LDL cholesterol, LDL protein, and LDL-C/P were a function of the absolute fall in VLDL cholesterol.

\section{DISCUSSION}

These data show that reciprocal changes in the cholesterol content of plasma VLDL and LDL occur commonly, if not universally, in metabolic states which lead to substantial changes in plasma glycerides and VLDL. They define conditions during which reciprocal lipoprotein changes occur consistently, i.e., when drug treatment or dietary changes result in large absolute changes in VLDL cholesterol and plasma glycerides. Every subject with large absolute changes in VLDL cholesterol has shown this inverse relationship except those with type III hyperlipoproteinemia.

Throughout this study, changes in total plasma cholesterol were small and inconsistent despite marked changes in the relative concentrations of individual lipoprotein classes. These data re-emphasize that total plasma cholesterol, by itself, only poorly reflects changes in individual lipoprotein classes.

Reciprocal changes in LDL and VLDL have been noted by other workers in a variety of circumstances (12-14). The fall in VLDL during dietary treatment of hyperlipemia by fat and caloric restriction was accompanied by reciprocal increases in LDL cholesterol,

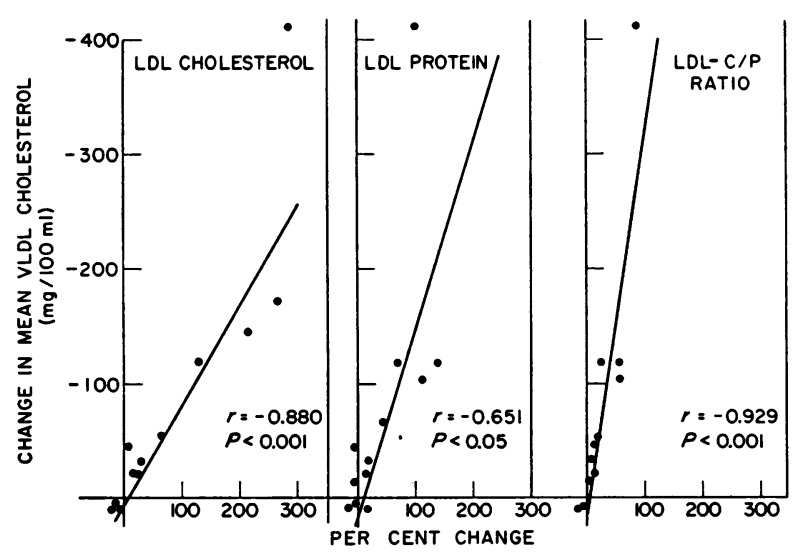

Figure 3 Linear regression analysis of the per cent change in $L D L$ cholesterol, LDL protein, and $L D L-C / P$ ratio vs. absolute change in VLDL cholesterol for the entire group of clofibrate-treated patients. Data from the two type III patients (18 and 20) are not included.
LDL protein, and LDL-C/P ratio in one report (14). Strisower, Adamson, and Strisower (13) reported a reciprocal rise in LDL as VLDL fell during clofibrate treatment. Our data on the effects of clofibrate therapy differ in several ways from those of Strisower and coworkers. Although the latter found an increase in LDL (, 0-20 lipoproteins) in patients with types IV and $\mathrm{V}$ hyperlipoproteinemia after clofibrate treatment, their data showed a slight LDL decrease in patients with type II hyperlipoproteinemia or type II accompanied by hyperprebetalipoproteinemia. Increases in LDL when present, were relatively smaller than those recorded here, perhaps as a result of the shorter time course of their study. The data are not entirely comparable, however, since Strisower measured total lipoprotein concentration in the analytical ultracentrifuge. whereas we measured specific lipoprotein components (i.e., LDL cholesterol and protein).

Short-term studies of plasma lipid and lipoprotein concentrations after acute metabolic perturbation have revealed sequential, similarly directed changes in VLDL and LDL (6). The time relationships have been relatively short, several hours to a few days. Our measurements were made at weekly intervals and so do not exclude the possibility that similarly directed changes in VLDL and LDL concentration occurred in the immediate postperturbation period.

An inverse relationship between HDL (alpha lipoprotein) concentration and VLDL concentration has been found after carbohydrate induction (2), intravascular lipolysis (2), in vitro incubation of VLDL with postheparin plasma (15), and clofibrate therapy (13). Our data are generally in accord with these observations; plasma HDL concentration changed inversely with VLDL in most instances. There were, however, large differences in the absolute and relative changes in HDL between patients.

The physiologic basis for these reciprocal changes in plasma VLDL and LDL-cholesterol concentrations is not clear. At least two possibilities exist: first, these changes may reflect differences in the rates of conversion of VLDL to LDL. Thus, if conversion of VLDL to LDL were accelerated, as might occur with clofibrate treatment (16), VLDL concentration would fall and LDL concentration would rise. On the other hand, plasma VLDL concentration itself might modulate the endogenous (hepatic) synthesis and secretion of LDL or its lipid components.

Numerous experimental data (1-4) and theoretical considerations, (4) which imply a precursor-product relationship between VLDL and LDL, are in support of the former possibility. Reciprocal changes might then result from changes in the rate of conversion of VLDL to LDL. The behavior of plasma LDL during carbo- 
hydrate induction is difficult to fit into this scheme, however, since neither LDL-protein nor LDL-cholesterol concentrations rose, despite the probable increase in VLDL synthesis and release into plasma (17). An additional effect of carbohydrate ( $\mathrm{CHO}$ ) induction on LDL synthesis or removal has not been described, to our knowledge.

If a major portion of LDL synthesis and release depends on de novo synthesis from nonlipoprotein precursors, then feedback inhibition by VLDL or VLDL constituents might determine plasma LDL concentration in a reciprocal fashion. LDL-glyceride synthesis is an unlikely regulatory site since LDL glycerides rise as plasma VLDL increases (18). Hepatic cholesterol synthesis, however, is subject to feedback inhibition by chylomicron cholesterol at the hydroxymethylglutarylCoA reductase step $(19,20)$. If VLDL also have the capacity to inhibit hepatic cholesterogenesis, and if this process is rate-limiting in LDL synthesis and release, then LDL cholesterol and LDL-C/P would vary inversely with VLDL-cholesterol concentration. Moreover, the changes in LDL cholesterol and LDL-C/P would be expected to be more pronounced than those in LDL protein. Our data are in accord with such an hypothesis but do not exclude alternative possibilities.

This study confirms the failure of LDL concentration to change as VLDL falls during treatment in type III hyperlipoproteinemia (13). From the limited number of patients studied thus far, the failure of VLDL-LDL reciprocity appears to be characteristic of this disorder and may provide further evidence for a defect in VLDL catabolism in type III (21).

These data have several practical implications. During therapeutic weight loss or clofibrate administration, LDL-cholesterol concentration will often rise as VLDL falls. In some instances, hyperbetalipoproteinemia, a potentially more serious abnormality (22), may result. Two patients in our series (15 and 19) showed LDL cholesterol increases to levels above defined normal limits (22) after clofibrate. In patient 15, LDL cholesterol gradually returned to normal. The other patient (19) died suddenly after 4 months of treatment. If total plasma cholesterol falls only slightly or even rises despite a significant drop in plasma glycerides during treatment of hyperlipidemia, the validity of such therapy should be reconsidered.

In the treatment of patients with type II hyperlipoproteinemia, one can make a rough prediction concerning the response of plasma LDL concentration to clofibrate therapy. Many patients with type II hyperlipoproteinemia and increased VLDL concentrations (type II B) will have an increase in plasma LDL concentration. In such cases, adjunctive or alternative drug therapy will probably be appropriate.

\section{ACKNOWLEDGMENTS}

We thank Margaret Miller and Martha McCluskey for dietetic and nursing assistance, respectively, and Carolyn Flowers, Gene DiBenedetto, and Josefina Sabio for laboratory assistance.

This work was supported by grants (RR-88) from the General Clinical Research Centers Program of the Division of Research Resources, National Institutes of Health, the National Heart and Lung Institute (HE 12621), the National Dairy Council (108), and the American Heart Association (69-714).

\section{REFERENCES}

1. Gustafson, A., P. Alaupovic, and R. H. Furman. 1964. Studies on the composition and structure of serum lipoproteins: physical-chemical characterization of phospholipid-protein residues obtained from very low-density human serum lipoproteins. Biochim. Biophys. Acta. 84: 767.

2. Levy, R. I., R. S. Lees, and D. S. Fredrickson. 1966. The nature of pre-beta (very low density) lipoproteins. J. Clin. Invest. $45: 63$.

3. Gitlin, D., D. G. Cornwell, D. Nakasato, J. L. Oncley, W. L. Hughes, Jr., and C. H. Janeway. 1958. Studies on metabolism of plasma proteins in nephrotic syndrome. II. Lipoproteins. J. Clin. Invest. 37: 172.

4. Langer, T., D. Bilheimer, and R. I. Levy. 1970. Plasma low density lipoprotein (LDL) : a remnant of very low density lipoprotein (VLDL) catabolism? Circulation. 42 (Suppl. III) : 7.

5. Gofman, J. W., O. DeLalla, F. Glazier, N. K. Freeman, F. T. Lindgren, A. V. Nichols, B. Strisower, and A. R. Tamplin. 1954. The serum lipoprotein transport system in health, metabolic disorders, atherosclerosis and coronary heart disease. Plasma. 2: 413.

6. Carlson, L. A., L. Orö, and J. Östman. 1968. Effect of nicotinic acid on plasma lipids in patients with hyperlipoproteinemia during the first week of treatment. $J$. Atheroscler. Res. 8: 667.

7. Ahrens, E. H., Jr., V. P. Dole, and D. H. Blankenhorn. 1954. The use of orally-fed liquid formulas in metabolic studies. Amer. J. Clin. Nutr. 2: 336.

8. Block, W. D., K. J. Jarrett, Jr., and J. B. Levine. 1966. An improved automated determination of serum total cholesterol with a single color reagent. Clin. Chem. 12: 681.

9. Kessler, G., and H. Lederer. 1966. Fluorometric measurement of triglycerides. Technicon Symposia, 1965. Automation in Clinical Chemistry. Mediaid, Inc., New York. 341.

10. Hatch, F. T., and R. S. Lees. 1968. Practical methods for plasma lipoprotein analysis. Advan. Lipid Res. 6: 1.

11. Lees, R. S. 1970. Immunoassay of plasma low-density lipoproteins. Science (Washington). 169: 493.

12. Nichols, A. V. 1969. Functions and interrelationships of different classes of plasma lipoproteins. Proc. Nat. Acad. Sci. U.S. A. $64: 1128$.

13. Strisower, E. H., G. Adamson, and B. Strisower. 1968. Treatment of hyperlipidemias. Amer. J. Med. 45: 488.

14. Havel, R. J., and R. S. Gordon, Jr. 1960. Idiopathic hyperlipemia: metabolic studies in an affected family. J. Clin. Invest. 39 : 1777.

15. Shore, B., and V. Shore. 1962. Some physical and 
chemical properties of the lipoproteins produced by lipolysis of human serum $S_{\mathbf{f}} 20-400$ lipoproteins by postheparin plasma. J. Atheroscler. Res. 2: 104.

16. Wolfe, B., J. Kane, R. Havel, and H. Brewster. 1970. Splanchnic metabolism in healthy young men given clofibrate. Circulation. 42 (Suppl. III) : 2.

17. Quarfordt, S. H., A. Frank, D. M. Shames, M. Berman, and D. Steinberg. 1970. Very low density lipoprotein triglyceride transport in type IV hyperlipoproteinemia and the effects of carbohydrate-rich diets. J. Clin. Invest. $49: 2281$.

18. Lindgren, F. T., N. K. Freeman, and A. V. Nichols. 1965. Physical and chemical properties of the lowdensity lipoproteins and their analysis by refractometry. In Metabolism of Lipids as Related to Atherosclerosis.
F. A. Kummerow, editor. Charles C. Thomas, Publisher, Springfield, Ill. 62.

19. Weis, H. J., and J. M. Dietschy. 1969. Failure of bile acids to control hepatic cholesterogenesis: evidence for endogenous cholesterol feedback. J. Clin. Invest. 48: 2398.

20. Dietschy, J. M., and J. D. Wilson. 1970. Regulation of cholesterol metabolism. N. Engl. J. Med. 282: 1128.

21. Hazzard, W. R., F. T. Lindgren, and E. L. Bierman. 1970. Very low density lipoprotein subfractions in a subject with broad- $\beta$ disease (type III hyperlipoproteinemia). J. Clin. Invest. $49: 1853$.

22. Fredrickson, S. R., R. I. Levy, and R. S. Lees. 1967. Fat transport in lipoproteins-an integrated approach to mechanisms and disorders. N. Engl. J. Med. 276: 32. 